\title{
PEMANFAATAN JERAMI PADI DENGAN BERBAGAI TEKNOLOGI PENGOLAHAN PAKAN TERHADAP PERSENTASE NON KARKAS DAN PERSENTASE DAGING TANPA TULANG PADA DOMBA JANTAN LOKAL
}

\section{(Utililization of The Rice Straw with Feed Processing Technology For Non Carcass and Boneless Percentage on Local Rams}

\author{
Deniel Turnip $^{1}$, R. Edhy Mirwandhono ${ }^{2}$ dan Hasnudi ${ }^{2}$ \\ 1: Mahasiswa Program Studi Peternakan Fakultas Pertanian Universitas Sumatera Utara \\ 2: Staf Pengajar Program Studi Peternakan Fakultas Pertanian Universitas Sumatera Utara
}

\begin{abstract}
Rice straw is an agricultural waste in Indonesia that can be used as animal feed. This research aimed to determine the effect of feed processing technologies for non carcass percentage boneless percentage on the local ram ( $\pm 6-8$ month). The design used in this research was completely randomized design with 4 treatments and 5 replications. The treatments consists of P1 (mechanically treated rice straw with chopper), P2 (chemically treated rice straw with 2-3\% NaOH), P3 (biologically treated rice straw with Aspergillus niger) and P4 (rice straw treated mechanically,chemically and biologically). The results showed that the percentage of head weight (\%) for the treatment of $P 1, P 2, P 3$ and P4 were 9.06; 9.81; 9.36, and 9.65, respectively. Tthe percentage of foot weight (\%) were $4.41 ; 4.84 ; 4.21$, and 4.64 , the percentage of skin weight $(\%)$ were $7.07 ; 8.65 ; 8.88$ and 8.79 , the percentage of internal organs weights (\%) were 12.77; 11.66; 12.56 and 11.20 and boneless percentage (\%) 64.47; 63.43; 69.21, and 65.04. Results of variance analysis showed that the rice straw feed processing technology significantly decreased the percentage weight of the head, feet, skin and internal organs $(P>0.05)$, but significantly increased the percentage of boneless meat $(P<0.05)$. Conclusion of the study is the utilization of feed technology on rice straw were not give significantly different effect on percentage weight of the head, feet, skin and internal organs and give significantly effect on percentage of boneless meat.
\end{abstract}

Keywords: Ram, Rice Straw, Aspergillus niger, non carcass and Boneless

\section{ABSTRAK}

Jerami padi merupakan limbah pertanian yang terbesar di Indonesia yang dapat dimanfaatkan sebagai pakan ternak. Penelitian ini bertujuan untuk mengetahui pengaruh teknologi pengolahan pakan pada jerami padi terhadap persentase non karkas dan persentase daging tanpa tulang pada domba jantan lokal umur $\pm 6-8$ bulan. Rancangan yang digunakan dalam penelitian ini adalah rancangan acak lengkap dengan 4 perlakuan dan 5 ulangan. Perlakuan terdiri atas P1 (jerami padi diolah secara mekanik dengan chopper), P2 (jerami padi diolah secara kimiawi dengan $\mathrm{NaOH}$ konsentrasi 2-3\%), P3 (jerami padi diolah secara biologi dengan Aspergillus niger) dan P4 (jerami padi diolah secara mekanik, kimiawi dan biologi). Hasil penelitian menunjukkan persentase bobot kepala (\%) pada perlakuan P1, P2, P3 dan P4 adalah 9,06; 9,81; 9,36; dan 9,65, persentase bobot kaki (\%) 4,41; 4,84; 4,21; dan 4,64, persentase bobot kulit (\%) 7,07; 8,65; 8,88 dan 8,79, persentase bobot organ dalam (\%) 12,$77 ; 11,66 ; 12,56$ dan 11,20 dan persentase boneless $(\%) 64,47^{\text {ab }} ; 63,43^{\mathrm{a}} ; 69,21^{\mathrm{b}}$; dan $65,04^{\mathrm{ab}}$. Hasil analisis ragam menunjukkan bahwa pemberian jerami padi dengan pengolahan teknologi pakan secara signifikan menurunkan persentase bobot kepala, kaki, kulit dan organ dalam $(\mathrm{P}>0,05)$, tetapi secara signifikan menaikkan persentase daging tanpa tulang $(\mathrm{P}>0,05)$. Kesimpulan hasil penelitian penggunaan teknologi pakan pada jerami padi memberikan pengaruh tidak berbeda nyata terhadap persentase bobot kepala, kaki, kulit dan organ dalam dan memberikan perbedaan yang nyata terhadap persentase daging tanpa tulang.

Kata kunci: Domba, Jerami Padi, Aspergillus niger, Non Karkas, dan Daging tanpa Tulang 


\section{PENDAHULUAN}

Jerami padi merupakan limbah pertanian yang paling potensial dijadikan pakan ternak dan terdapat hampir diseluruh daerah di Indonesia dengan produksi sekitar 52 juta ton bahan kering per tahun. Dari jumlah tersebut sebagian besar dihasilkan di Pulau Jawa dan Bali yaitu sebanyak 21 juta ton bahan kering per tahun (BPS, 2004). Lahan sawah di Indonesia berdasarkan Badan Pusat Statistik (BPS) tahun 2002 luasnya sekitar 7,75 juta ha. Jerami padi merupakan limbah pertanian terbesar di Indonesia. Produksi per hektar sawah bisa mencapai $12-15$ ton bahan kering setiap kali panen, tergantung lokasi dan varietas tanaman. Sejauh ini, pemanfaatan jerami padi sebagai pakan ternak baru mencapai $31-39 \%$, sedangkan yang dibakar atau dimanfaatkan sebagai pupuk $36-62 \%$, dan sekitar $7-16 \%$ digunakan untuk keperluan industri.

Penggunaan jerami secara langsung atau sebagai pakan tunggal tidak dapat memenuhi kebutuhan nutrisi ternak. Dengan pengolahan, daya cerna jerami padi dapat ditingkatkan hingga $70 \%$ dan kandungan proteinnya dapat mencapai 5 - $8 \%$. Menurut Arora (1995), kadar lignin pada jerami padi tinggi sekali yaitu lebih dari $10 \%$. Walaupun pada kenyataannya jerami padi miskin akan zat-zat makanan, namun sekitar $40 \%$ dapat dicerna sebagai sumber energi dalam proses pencernaan ternak ruminansia (Arinong, 2009). Untuk memanfaatkan jerami padi sebagai pakan ternak secara optimal perlu dilakukan pengolahan dengan sentuhan teknologi untuk meningkatkan kualitasnya, baik pengolahan secara fisik, kimiawi maupun biologis. Pengolahan secara fisik dilakukan secara chopper, secara kimiawi direndam dengan $\mathrm{NaOH}$ konsentrasi 2-3\%, pengolahan secara biologis dilaakukan dengan fermentasi oleh Aspergillus niger dan pengolahan secara kombinasi dilakukan dengan chopper lalu difermentasi dan direndam dengan $\mathrm{NaOH}$.

Berdasarkan uraian di atas maka penulis tertarik untuk menelaah sejauh mana peluang pemanfaatan jerami padi dipergunakan sebagai pakan untuk ternak ruminansia. Penulis akan mengolah jerami padi tersebut dengan pengolahan secara mekanik, kimia dan biologis menjadi pakan yang lebih baik dan mampu meningkatkan persentase non karkas dan persentase boneless. 


\section{BAHAN DAN METODE PENELITIAN}

\section{Lokasi dan Waktu Penelitian}

Penelitian dilaksanakan di Laboratorium Biologi Ternak Program Studi Peternakan Fakultas Pertanian Universitas Sumatera Utara. Penelitian ini berlangsung selama 4 bulan dimulai dari bulan Juli 2012 sampai dengan oktober 2012.

\section{Bahan dan Alat Penelitian}

Bahan yang digunakan antara lain: Domba lokal jantan umur $\pm 6-8$ bulan sebanyak 20 ekor dengan rataan bobot badan awal $11,16 \mathrm{~kg} \pm 0,98$, pakan konsentrat yang terdiri dari bungkil inti sawit, dedak padi, molasses, pod kakao, urea, mineral mix dan garam. Jerami padi sebagai pengganti pakan rumput ternak, urea sebagai bahan amoniasi jerami padi dan penyusun konsentrat, Aspergilus niger untuk fermentasi jerami padi, $\mathrm{NaOH}$ untuk pengolahan jerami padi secara kimiawi, obat-obatan seperti obat cacing (verymizin), anti bloat untuk obat gembung, Rhodallon untuk desinfektan dan vitamin. Air minum diberikan secara ad libitium.

Alat yang digunakan antara lain: Kandang individual 20 unit dengan ukuran $1 \times 0,5 \mathrm{~m}$ beserta perlengkapannya, tempat pakan dan minum, timbangan untuk menimbang bobot hidup berkapasitas $50 \mathrm{~kg}$ dengan kepekaan $2 \mathrm{~kg}$, timbangan berkapasitas $2 \mathrm{~kg}$ dengan kepekaan $10 \mathrm{~g}$ untuk menimbang pakan, chooper digunakan untuk menchopper bahan pakan, grinder digunakan untuk menghaluskan bahan pakan, lemari es untuk menyimpan daging domba, pisau untuk pemotongan, thermometer digunakan untuk mengetahui suhu di dalam dan diluar kandang, alat pembersih kandang, alat penerangan kandang.

Kandungan nutrisi jerami padi yang diolah secara mekanik, kimiawi, biologi dan kombinasi tersaji pada Tabel 1 .

Tabel 1. Kandungan nutrisi jerami padi pada perlakuan

\begin{tabular}{|c|c|c|c|}
\hline \multirow{2}{*}{ No. } & \multirow{2}{*}{ Bahan/Jenis sampel } & \multicolumn{2}{|c|}{ Jenis analisa $(\%)$} \\
\hline & & SK & PK \\
\hline 1. & Jerami padi yang diolah secara chopper & 28,08 & 4,35 \\
\hline 2. & Jerami padi yang diolah secara kimiawi & 26,15 & 4,50 \\
\hline 3. & Jerami padi yang diolah secara biologi & 24,14 & 6,03 \\
\hline 4. & Jerami padi yang diolah secara kombinasi & 23,16 & 5,59 \\
\hline
\end{tabular}

Sumber: Laboratorim Ilmu Nutrisi dan Pakan Ternak Program Studi Peternakan (2012). 
Komposisi susunan konsentrat pada pakan domba selama penelitian tersaji pada Tabel 2.

Tabel 2. Komposisi susunan konsentrat :

\begin{tabular}{|c|c|c|c|c|c|c|}
\hline \multicolumn{2}{|r|}{ Bahan } & \multirow{2}{*}{$\frac{\% \text { Bahan }}{13}$} & \multirow{2}{*}{$\frac{\% \mathrm{PK}}{0,96}$} & \multirow{2}{*}{$\frac{\% \text { SK }}{4,30}$} & \multirow{2}{*}{$\frac{\% \text { LK }}{0,18}$} & \multirow{2}{*}{$\frac{\% \text { TDN }}{6,39}$} \\
\hline 1 & Kulit Buah Kakao & & & & & \\
\hline 2 & Bungkil Inti Sawit & 20 & 3,08 & 3,38 & 0,48 & 16,2 \\
\hline 3 & Dedak Padi & 18 & 2,48 & 2,02 & 1,48 & 11,57 \\
\hline 4 & Onggok & 27 & 0,43 & 2,81 & 0,11 & 20,52 \\
\hline 5 & Tepung daun singkong & 13 & 3,25 & 1,56 & 0,91 & 11,77 \\
\hline 6 & Molasses & 5 & 0,2 & 0,02 & 0.0 & 4,05 \\
\hline 7 & Garam & 1 & 0 & 0 & 0 & 0 \\
\hline 8 & Mineral & 1 & 0 & 0 & 0 & 0 \\
\hline \multirow[t]{2}{*}{9} & Urea & 2 & 5,60 & 0 & 0 & 0 \\
\hline & Total & 100 & 16 & 14,09 & 3,16 & 70,5 \\
\hline
\end{tabular}

\section{Metode Penelitian}

Metode penelitian yang dilakukan adalah rancangan acak lengkap (RAL) dengan 4 perlakuan dan 5 ulangan, yaitu:

$\mathrm{P} 1=$ Jerami padi diolah secara mekanik (chopper) + Konsentrat

$\mathrm{P} 2=$ Jerami padi diolah secara kimiawi $(\mathrm{NaOH})+$ Konsentrat

P3 = Jerami padi diolah secara biologi $($ Aspergillus niger $)+$ Konsentrat

P4 = Jerami padi diolah secara mekanik, kimiawi dan biologis (kombinasi) + Konsentrat

Menurut Hanafiah (2003), metode linier percobaan yang digunakan adalah:

Keterangan:

$$
\mathbf{Y i j}=\boldsymbol{\mu}+\mathbf{T i}+\mathbf{\varepsilon i j}
$$

$\mathrm{i} \quad=1,2, \ldots \mathrm{t}$ (perlakuan)

$\mathrm{j}=1,2, \ldots \mathrm{r}$ (ulangan)

Yij = nilai pengamatan yang diperoleh dari perlakuan ke-i dan ulangan ke-j.

$\mu=$ nilai tengah umum.

$\mathrm{Ti}=$ pengaruh perlakuan ke-i.

$\boldsymbol{\varepsilon} \mathbf{i j}=$ pengaruh galat percobaan dari perlakuan pengujian ke-i dan ulangan ke-j.

\section{Parameter Penelitian}

1. Persentase bobot kepala

Persentase bobot kepala diperoleh dari perbandingan bobot kepala dengan bobot tubuh kosong dikali $100 \%$. 
2. Persentase bobot kaki

Persentase bobot kaki diperoleh dari perbandingan bobot kaki dengan bobot tubuh kosong dikali $100 \%$.

3. Persentase bobot kulit

Persentase bobot kulit diperoleh dari perbandingan bobot kulit dengan bobot tubuh kosong dikali $100 \%$.

4. Persentase bobot organ dalam

Persentase bobot organ dalam diperoleh dari perbandingan bobot organ dalam dengan bobot tubuh kosong dikali 100\%.

5. Persentase bobot daging tanpa tulang

Persentase bobot daging tanpa tulang ini diperoleh dari hasil pemisahan daging dari tulang yang mana karkas telah disimpan dalam lemari es selama 24 jam kemudian ditimbang sesuai perlakuan lalu dibagi bobot karkas dikali 100\% (Herman, 1993).

\section{Cara Pengolahan Jerami Padi}

\section{Cara Biologi}

Jerami padi dichopper atau dicacah sepanjang 5-10 cm, lalu dimasukkan ke dalam bak fermentasi. Kemudian disiram dengan air sumur, lalu ditaburi Aspergillus niger dan dicampur merata. Ditutup dengan menggunakan sabut kelapa. Difermentasi selama 2 minggu. Setelah itu jerami padi dijemur dan diangin-anginkan. Jerami padi siap diberikan pada ternak.

\section{Cara kimiawi}

Jerami padi dichopper atau dicacah sepanjang $5-10 \mathrm{~cm}$, larutkan 50 gram $\mathrm{NaOH}$ ke dalam 2,5 liter air untuk setiap kilogram jerami padi dalam tong besar. Kemudian masukkan jerami padi yang sudah dichopper ke dalam larutan $\mathrm{NaOH}$ sampai menyerap dan biarkan selama 24 jam. Setelah itu jemur dan angin-anginkan selama 48 jam. Jerami padi siap diberikan pada ternak (Ismail, 2011).

\section{HASIL DAN PEMBAHASAN}

Rekapitulasi hasil penelitian terhadap persentase bobot kepala, kaki, kulit, organ dalam dan daging tanpa tulang dapat dilihat pada Tabel 3. 
Tabel 3. Rekapitulasi hasil penelitian

\begin{tabular}{cccccc}
\hline Perlakuan & $\begin{array}{c}\text { Persentase bobot } \\
\text { kepala (\%) }\end{array}$ & $\begin{array}{c}\text { Persentase bobot } \\
\text { kaki (\%) }\end{array}$ & $\begin{array}{c}\text { Persentase } \\
\text { bobot kulit (\%) }\end{array}$ & $\begin{array}{c}\text { Persentase bobot organ } \\
\text { dalam (\%) }\end{array}$ & $\begin{array}{c}\text { Persentase daging } \\
\text { tanpa tulang (\%) }\end{array}$ \\
\hline P1 & $9,06^{\text {tn }} \pm 1,14$ & $4,41^{\text {tn }} \pm 0,21$ & $7,07^{\text {tn }} \pm 0,18$ & $12,77^{\text {tn }} \pm 0,27$ & $64,47 \pm 0,91^{\mathrm{ab}}$ \\
P2 & $9,81^{\text {tn }} \pm 0,12$ & $4,84^{\text {tn }} \pm 0,34$ & $8,65^{\text {tn }} \pm 0,67$ & $11,66^{\text {tn }} \pm 1,38$ & $63,43 \pm 0,65^{\mathrm{a}}$ \\
P3 & $9,36^{\text {tn }} \pm 0,34$ & $4,21^{\text {tn }} \pm 0,12$ & $8,88^{\text {tn }} \pm 1,58$ & $12,56^{\text {tn }} \pm 0,47$ & $69,21 \pm 0,87^{\mathrm{b}}$ \\
P4 & $9,65^{\text {tn }} \pm 0,65$ & $4,64^{\text {tn }} \pm 0,26$ & $8,79^{\text {tn }} \pm 0,60$ & $11,20^{\text {tn }} \pm 1,48$ & $65,04 \pm 2,16^{\text {ab }}$ \\
\hline
\end{tabular}

Keterangan: $\mathrm{tn}=$ tidak nyata berbeda $(\mathrm{P}>0,05)$

$\mathrm{a}, \mathrm{b}=$ berbeda nyata $(\mathrm{P}<0,05)$

\section{Persentase Bobot Kepala}

Persentase bobot kepala diperoleh dari bobot kepala domba dibagi bobot tubuh kosong dikali seratus persen (Herman, 1993). Pada Tabel 3 dapat dilihat bahwa rataan persentase bobot kepala tertinggi diperoleh P2 (jerami padi diolah secara kimiawi $(\mathrm{NaOH})+$ konsentrat) yaitu sebesar 9,81\% dan yang terendah pada P1 (jerami padi diolah secara mekanik (chopper) + konsentrat) yaitu sebesar 9,06\%.

Hasil analisis ragam menunjukkan hasil yang tidak berbeda nyata terhadap persentase bobot kepala. Menurut Soeparno (1994), konsumsi nutrisi tinggi meningkatkan berat hati, rumen, omasum, usus besar, usus kecil dan total alat pencernaan, tetapi sebaliknya bagi berat kepala dan kaki perlakuan dan nutrisi serta spesies pastura dan pangonan pada domba tidak mempengaruhi berat kepala, kaki dan kulit pada berat tubuh yang sama. Hal ini dapat disimpulkan bahwa kandungan nutrisi pakan tidak mempengaruhi bobot kepala, kaki dan kulit.

\section{Persentase Bobot Kaki}

Persentase bobot kaki diperoleh dari bobot kaki domba dibagi bobot tubuh kosong dikali seratus persen (Herman, 1993). Pada Tabel 3 dapat dilihat bahwa rataan persentase bobot kaki domba yaitu sebesar 4,52\%. Persentase bobot kaki tertinggi diperoleh P2 (jerami padi diolah secara kimiawi $(\mathrm{NaOH})+$ konsentrat) yaitu sebesar $4,84 \%$ dan yang terendah pada P3 (jerami padi diolah secara biologi (Aspergillus niger)+ konsentrat) yaitu sebesar 4,21\%.

Hasil analisis ragam menunjukkan hasil yang tidak berbeda nyata terhadap persentase bobot kaki. Hal ini sejalan dengan persentase bobot kepala. Menurut Soeparno (1994), konsumsi nutrisi tinggi meningkatkan berat hati, rumen, omasum, usus besar, usus kecil dan total alat 
pencernaan, tetapi sebaliknya bagi berat kepala dan kaki perlakuan dan nutrisi serta spesies pastura dan pangonan pada domba tidak mempengaruhi berat kepala, kaki dan kulit pada berat tubuh yang sama. Hal ini dapat disimpulkan bahwa kandungan nutrisi pakan tidak mempengaruhi bobot kepala, kaki dan kulit.

Perbedaan teknologi yang diterapkan pada jerami tidak memberikan persentase bobot kaki yang nyata sehingga dapat disimpulkan bahwa pemberian jerami padi yang diolah secara mekanik, kimiawi, biologi dan kombinasi dalam pakan domba lokal jantan memberikan pengaruh yang tidak berbeda nyata terhadap persentase bobot kaki. Pemberian nutrisi yang berbeda akan mempengaruhi rataan non karkas terhadap berat hidup. Pada penelitian ini pakan yang digunakan mempunyai kandungan nutrisi yang sama, sehingga tidak memberikan pengaruh yang berbeda terhadap bobot kaki.

\section{Persentase Bobot Kulit}

Persentase bobot kulit diperoleh dari bobot kulit dibagi bobot tubuh kosong dikali seratus persen (Herman, 1993). Pada Tabel 3 dapat dilihat bahwa rataan persentase bobot kulit tertinggi pada P3 (jerami padi diolah secara biologi (Aspergillus niger) + konsentrat) yaitu sebesar 8,88\% dan yang terendah pada P1 (jerami padi diolah secara mekanik (chopper) + konsentrat) sebesar 7,07\%.

Hasil analisis keragaman pada Tabel menunjukkan bahwa F hitung lebih kecil dari F Tabel $(\mathrm{P}>0,05)$ sehingga dapat disimpulkan bahwa pemberian jerami padi yang diolah secara mekanik, kimiawi, biologi dan kombinasi dalam pakan domba lokal jantan memberikan pengaruh yang tidak berbeda nyata terhadap persentase bobot kulit.

Domba yang mengkonsumsi pakan dengan kandungan energi yang tinggi, mempunyai jantung yang lebih berat dari pada domba yang mengkonsumsi pakan dengan kandungan energi rendah pada kondisi pemeliharaan di dalam kandang individu. Konsumsi nutrisi tinggi meningkatkan berat hati, rumen, omasum, usus besar, usus kecil dan total alat pencernaan, tetapi sebaliknya bagi berat kepala dan kaki perlakuan dan nutrisi serta spesies pastura dan pangonan pada domba tidak mempengaruhi berat kepala, kaki, dan kulit pada berat tubuh yang sama.

Bobot kulit ini diambil dari kulit bagian tubuh, kulit kepala dan kulit kaki. Pertumbuhan ternak terdiri atas tahap cepat yang terjadi mulai awal sampai pubertas dan tahap lambat yang terjadi pada saat kedewasaan tubuh telah tercapai. Pada waktu kecepatan pertumbuhan 
mendekati konstan. Dalam hal ini pertumbuhan otot, tulang dan organ-organ penting mulai berhenti, sedangkan penggemukan (fattening) mulai dipercepat.

\section{Persentase Bobot Organ Dalam}

Persentase bobot organ dalam diperoleh dari bobot organ dalam dibagi bobot potong dikali seratus persen (Herman, 1993). Rataan persentase bobot organ dalam domba yaitu sebesar $12,05 \%$. Persentase bobot organ dalam tertinggi diperoleh P1 (jerami padi diolah secara mekanik (chopper) + konsentrat) yaitu sebesar $12,77 \%$ dan yang terendah pada P4 (jerami padi diolah secara kombinasi + konsentrat) yaitu sebesar $11,20 \%$.

Hasil analisis ragam pada Tabel menunjukkan bahwa $\mathrm{F}$ hitung lebih kecil dari $\mathrm{F}$ Tabel $(\mathrm{P}>0,05)$ sehingga dapat disimpulkan bahwa pemberian jerami padi yang diolah secara mekanik, kimiawi, biologi dan kombinasi dalam pakan domba lokal jantan memberikan pengaruh yang tidak berbeda nyata terhadap persentase bobot organ dalam.

Hasil yang tertinggi diperoleh P1 sebesar 12,77\% walau tidak berbeda nyata dengan P3 sebesar 12,56\%. Menurut Berg dan Butterfield,1976 disitasi Ginting, (2011), kadar laju pertumbuhan beberapa komponen non karkas hampir sama dengan kadar laju pertumbuhan tubuh, misalnya abomasum dan usus besar mencapai kedewasaan hampir bersamaan dengan tubuh. Usus kecil tumbuh lebih cepat dari pada usus besar dan abomasum. Berat rumen retikulum dan omasum meningkat dengan cepat pada awal kehidupan post natal. Meskipun demikian berat total saluran pencernaan menurun pada saat mencapai kedewasaan. Sedangkan menurut Soeparno (1994), konsumsi nutrisi tinggi meningkatkan berat hati, rumen, omasum, usus besar, usus kecil dan total alat pencernaan, tetapi sebaliknya bagi berat kepala dan kaki perlakuan dan nutrisi serta spesies pastura dan pangonan pada domba tidak mempengaruhi berat kepala, kaki dan kulit pada berat tubuh yang sama.

\section{Persentase Daging tanpa Tulang (Boneless)}

Persentase boneless dapat diperoleh dari perbandingan bobot boneless dengan bobot karkas dikali seratus persen. Rataan persentase boneless pada domba jantan lokal yaitu sebesar 65,54\%. Rataan persentase boneless yang tertinggi terdapat pada perlakuan P3 (jerami padi yang diolah secara biologis dengan Aspergillus niger + konsentrat) yaitu sebesar 69,21\% dan rataan 
persentase non karkas terendah diperoleh dari perlakuan P4 (jerami padi yang diolah secara kombinasi + konsentrat) yaitu sebesar 65,04\%.

Hasil yang diperoleh dari penelitian sesuai dengan pendapat Herman (1984), yang mengemukakan bahwa persentase daging domba lokal adalah 60\% sedangkan persentase tulangnya 30\% tetapi masih berada di bawah 75\% seperti pendapat Wardjojo (1993), yang menyatakan persentase daging dalam karkas sebesar 75\%. Hal ini diasumsikan karena pengaruh bobot karkas yang berbeda nyata dalam penelitian.

Persentase boneless ini juga dapat dipengaruhi oleh umur, jenis kelamin dan bangsa ternak. Hal ini sesuai dengan pernyataan Hendri, (1986) yang menyatakan bahwa daging domba mengandung protein $17,1 \%$ dan lemak $14,8 \%$. Variasi distribusi perdagingan pada ternak ruminansia kecil disebabkan oleh beberapa faktor seperti spesies, bangsa, umur, nutrisi, jenis kelamin, aktifitas ternak dan tatalaksana pemeliharaan.

Hasil penelitian persentase boneless menunjukkan perbedaan yang nyata $(\mathrm{P}<0,05)$. Data ini diperoleh dari daging yang ada pada bagian karkas yang telah dipisahkan dengan tulang. Ini berarti data persentase karkas juga berpengaruh terhadap persentase boneless ini. Persentase karkas juga memberikan pengaruh yang berbeda nyata, hal ini yang mengakibatkan persentase boneless juga memberikan pengaruh yang sama.

Pada Tabel 3 dapat dilihat bahwa persentase boneless yang tertinggi terdapat pada P3 yaitu sebesar 69,21\%. Angka ini masih berada di bawah 75\%. Ini berarti persentase boneless ini masih dikatakan rendah walaupun secara statistik hasilnya menunjukkan perbedaan yang nyata. Hal ini sejalan dengan pendapat Wardjojo (1993), yang menyatakan persentase daging dalam karkas sebesar 75\%. Hal ini diasumsikan karena jerami padi mempunyai kandungan nutrisi yang rendah dan memiliki serat kasar dan lignin yang tinggi sehingga sulit dicerna oleh ternak. Semakin sedikit nutrisi yang diserap maka semakin sedikit pula daging yang terbentuk. Pengolahan yang dilakukan pada jerami padi hanya mampu meningkatkan kandungan nutrisinya sedikit dan menurunkan serat kasarnya juga sedikit.

Pemberian jerami padi memberikan perbedaan yang nyata pada persentase boneless. Peneliti berasumsi bahwa jerami padi memberikan pengaruh yang positif pada boneless. Jika dibandingkan dengan data yang lainnya yang menunjukkan perbedaan yang tidak nyata antar 
perlakuan, maka peneliti menyimpulkan bahwa pemberian jerami padi hanya berpengaruh baik pada persentase boneless.

Hasil uji BNJ 5\% (Tabel 3) dapat dilihat bahwa perlakuan P3 (jerami padi difermentasi Aspergillus niger) memberikan pengaruh yang berbeda nyata terhadap perlakuan P2 (jerami padi dengan $\mathrm{NaOH}$ ), tetapi memberikan pengaruh yang tidak nyata berbeda dengan perlakuan P1 (jerami padi yang dichopper) dan P4 (jerami padi yang diolah secara kombinasi). Dari hasil uji lanjut dapat disimpulkan bahwa P3 lebih potensial dibandingkan dengan perlakuan lainnya.

\section{KESIMPULAN}

Berdasarkan hasil penelitian pemanfaatan jerami padi dengan pengolahan teknologi pakan (fisik, kimiawi dan biologi) tidak memberikan perbedaan yang nyata terhadap kualitas non karkas dan persentase lemak subkutan dan memberikan perbedaan yang nyata terhadap persentase boneless yang mana perlakuan P3 (Aspergillus niger) memberikan hasil yang paling tinggi yaitu sebesar $69,21 \%$.

\section{DAFTAR PUSTAKA}

Arinong, A., 2009. Pemanfaatan Jerami Padi untuk Konservasi dan Pakan Ternak. STTP Gowa. http://www.stppgowa.ac.id. Diakses tanggal 2 Februari 2012.

Arora, S. P. 1995. Pencernaan Mikrobiologi pada Ruminansia. UGM Press, Yogyakarta.

Badan Pusat Statistik Sumatera Utara, 2002. Statistika Indonesia. Biro Pusat Statistik Indonesia. Jakarta. Jakarta. , 2004. Statistika Indonesia. Biro Pusat Statistik Indonesia.

Berg, R. T. dan R. Butterfield. 1976. New Concept of Cattle Growth. Sidney University Press, Sydney.

Hanafiah, K.A., 2003. Rancangan Percobaan. Fakultas Pertanian, Universitas Sriwijaya, Palembang.

Hendri. 1986. Studi perbandingan distribusi perdagingan kambing Kacang dan domba Priangan pada dua tingkat umur. Karya Ilmiah. Fakultas Peternakan. Institut Pertanian Bogor, Bogor.

Herman, R., 1993. Perbandingan Pertumbuhan Komposisi Tubuh dan Karkas Antara Domba Priangan dan Ekor Gemuk. Disertasi Program Pasca Sarjana, IPB, Bogor. 
Ismail, R., 2011. Teknologi Pengolahan Jerami. FAPET UNPAD. http://wordpress.com/2011/11/19/teknologi-pengolahan-jerami. [10 April 2012].

Soeparno. 1994. Ilmu dan Teknologi Daging. Gadjah Mada University Press. Yogyakarta. 